\title{
Isolation and Partial Characterization of an Adhesin from Candida albicans
}

\author{
By IAN A. CRITCHLEY AND L. JULIA DOUGLAS* \\ Department of Microbiology, University of Glasgow, Garscube Estate, Bearsden, \\ Glasgow G61 1QH, UK
}

(Received 30 July 1986; revised 17 October 1986)

Candida albicans produces extracellular polymeric material (EP) which contains a mannoprotein adhesin. EP isolated from culture supernatants of $C$. albicans GDH 2346 consisted of a mixture of glycoprotein components and inhibited yeast adhesion to buccal epithelial cells by up to $60 \%$. Partial purification of the adhesin was achieved by a two-step procedure involving chromatography of EP on concanavalin A-Sepharose and DEAE-cellulose. The purified adhesin inhibited adhesion to buccal cells 30 times more efficiently (on a weight basis) than unfractionated EP. Pretreatment of EP with heat, dithiothreitol or proteolytic enzymes either partially or completely destroyed its ability to inhibit adhesion, whereas pretreatment with sodium periodate or $\alpha$-mannosidase had little or no effect. These results suggest that the protein portion of the mannoprotein adhesin is more important than the carbohydrate moiety in mediating yeast attachment to buccal epithelial cells.

\section{INTRODUCTION}

The essential role of microbial adhesion in the pathogenesis of a number of infectious diseases is now well established. Most research in this area relates to bacterial adhesion, but recently there has been increasing interest in adhesion of the most important yeast pathogen, Candida albicans, to epithelial surfaces (reviewed by Douglas, 1985, 1987). Adhesion of some C. albicans strains in vitro can be promoted by growing the yeast in defined medium containing a high concentration of galactose as the carbon source (Douglas et al., 1981; McCourtie \& Douglas, $1981,1984)$. These conditions stimulate the production of a fibrillar-floccular layer on the yeast surface, a change which is presumed to account for the enhanced adhesion (McCourtie \& Douglas, 1981). A surface layer of similar morphology has been shown to mediate attachment of C. albicans to mucosal surfaces (Marrie \& Costerton, 1981) and renal endothelium (Barnes et al., 1983) in vivo.

Prolonged incubation of $C$. albicans in medium containing galactose causes release of surface fibrils, and extracellular polymeric material (EP) can be isolated from culture supernatants; EP appears, by adhesion inhibition tests, to contain the yeast adhesin (McCourtie \& Douglas, 1985). The present paper describes a partial purification and characterization of this adhesin.

\section{METHODS}

Organism. C. albicans GDH 2346 (NCYC 1467) was used throughout the study. This strain was originally isolated at Glasgow Dental Hospital from a patient with denture stomatitis. It was maintained on slopes of Sabouraud dextrose agar (Difco) and subcultured monthly. Every two months, cultures were replaced by new ones freshly grown from freeze-dried stocks.

Growth conditions. The yeast was grown at $37^{\circ} \mathrm{C}$, with shaking, in yeast nitrogen base medium (Difco) containing $500 \mathrm{~mm}$-galactose as described previously (McCourtie \& Douglas, 1981). It grows exclusively in the budding yeast phase under these conditions. Cells were harvested after $24 \mathrm{~h}$ (stationary phase of growth) and washed twice in $0 \cdot 15 \mathrm{M}$-phosphate-buffered saline, $\mathrm{pH} 7.2$ (PBS).

Abbreviations: AII, adhesion inhibition index; Con A, concanavalin A; EP, extracellular polymeric material. 
Adhesion assays. Yeast adhesion to exfoliated buccal epithelial cells was determined by light microscopy as

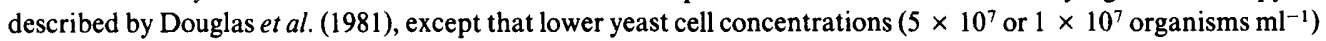
were used. In some experiments, washed buccal cells were preincubated with crude EP or EP fractions as follows. Epithelial cell suspensions $\left(1 \times 10^{5}\right.$ cells $\mathrm{ml}^{-1}$ in PBS; $\left.1 \mathrm{ml}\right)$ were centrifuged in a Beckman microfuge and the pellet was resuspended in EP solution $(1 \mathrm{ml})$. After incubation at $37^{\circ} \mathrm{C}$ for $30 \mathrm{~min}$ with gentle shaking, the buccal cells were recovered by centrifugation and resuspended in PBS $(1 \mathrm{ml})$ for use in adhesion assays.

Isolation of EP. EP was prepared by freeze-drying dialysed culture supernatants. Batches of medium ( $500 \mathrm{ml}$ in 2 litre Erlenmeyer flasks) were inoculated with overnight yeast cultures $(50 \mathrm{ml})$ and incubated at $37^{\circ} \mathrm{C}$ for $5 \mathrm{~d}$ in an orbital shaker operating at 150 r.p.m. Yeasts were removed by centrifugation and the culture supernatant fluid was dialysed at $4{ }^{\circ} \mathrm{C}$ for one week against five changes (12 litres each) of distilled water. The retentate (crude EP) was freeze-dried and weighed.

Analysis of EP. Protein was determined by the Lowry method and phosphorus by the method of Chen et al. (1956). Total carbohydrate was estimated according to the procedure of Dubois et al. (1956), using mannose as a standard.

Fractionation of EP. Crude EP (30-50 mg in $5 \mathrm{ml} \mathrm{PBS})$ was applied to a column $(1.5 \times 10.7 \mathrm{~cm})$ of concanavalin A-Sepharose 4B (Con A-Sepharose 4B, Sigma) and eluted with PBS until the absorbance at $280 \mathrm{~nm}$ of the eluate was negligible. The flow rate was $34 \mathrm{ml} \mathrm{h}^{-1}$ and the fraction volume was $3 \mathrm{ml}$. Bound material was eluted with $0.5 \mathrm{M}$-methyl $\alpha$-D-mannoside. Fractions were analysed for protein, phosphorus and total carbohydrate. Appropriate fractions were pooled, dialysed against distilled water and concentrated using Aquacide II (Calbiochem).

All of the material eluted by methyl $\alpha$-D-mannoside was subjected to further chromatography on DEAEcellulose. The pooled fractions were first dialysed against distilled water, concentrated and then applied to a column $(2.6 \times 58 \mathrm{~cm})$ of DE 52 (Whatman). The column was eluted with a linear gradient of $\mathrm{NaCl}(0-0.5 \mathrm{M})$ in $0 \cdot 15 \mathrm{M}$-potassium phosphate buffer $(\mathrm{pH} 7.2)$ at a flow rate of $20 \mathrm{ml} \mathrm{h}^{-1}$. Fractions $(3.2 \mathrm{ml})$ were analysed, and appropriate fractions were pooled, dialysed and concentrated as described above. Before any concentrated fraction was used as a potential inhibitor in adhesion assays, its content of protein and carbohydrate was determined.

Heat, chemical and enzyme treatments of EP. In some experiments, crude EP used to pretreat epithelial cells was first processed as follows.

(a) Heat treatment. Solutions of EP $\left(10 \mathrm{mg} \mathrm{m}^{-1}\right.$ in PBS $)$ were heated at $50^{\circ} \mathrm{C}, 80^{\circ} \mathrm{C}$ and $100^{\circ} \mathrm{C}$ in small, screwcapped bottles for $15 \mathrm{~min}$.

(b) Chemical treatments. Mild alkali treatment involved dissolving EP $\left(20 \mathrm{mg} \mathrm{ml}^{-1}\right)$ in $0.1 \mathrm{M}-\mathrm{NaOH}$ in a screwcapped bottle; the solution was incubated at $25^{\circ} \mathrm{C}$ for $24 \mathrm{~h}$ and then neutralized with $\mathrm{HCl}$ to give a final EP concentration of $10 \mathrm{mg} \mathrm{ml}^{-1}$. For mild acid-treatment, EP $\left(20 \mathrm{mg} \mathrm{ml}^{-1}\right)$ was heated in $0.01 \mathrm{M}-\mathrm{HCl}$ at $100^{\circ} \mathrm{C}$ for $30 \mathrm{~min}$ in a sealed ampoule and neutralized with $\mathrm{NaOH}$ to a final EP concentration of $10 \mathrm{mg} \mathrm{ml}^{-1}$. Dithiothreitol treatment was accomplished by dissolving EP $\left(10 \mathrm{mg} \mathrm{m}^{-1}\right)$ in $12 \mathrm{mM}$-dithiothreitol and incubating the solution at $37^{\circ} \mathrm{C}$ for $60 \mathrm{~min}$. Periodate treatment involved adding sodium periodate (final concentration $20 \mathrm{~mm}$ or $50 \mathrm{~mm}$ ) to a solution of EP $\left(5 \mathrm{mg} \mathrm{ml}^{-1}\right)$ in $0.05 \mathrm{M}$-sodium acetate buffer $(\mathrm{pH} 4.5)$. The mixture was incubated in the dark at $4{ }^{\circ} \mathrm{C}$ for $30 \mathrm{~min}$ and then the reaction was terminated by adding excess ethylene glycol. EP was recovered by precipitation with acetone, dried in a desiccator and redissolved in PBS.

(c) Enzyme treatments. Trypsin, chymotrypsin, pronase (from Streptomyces griseus; pronase E) and papain (all from Sigma) were used at concentrations of $0.1 \mathrm{mg} \mathrm{m}^{-1}$ in $0.01 \mathrm{M}$-potassium phosphate buffer (pH 7.2; $\mathrm{pH} 6.2$ for papain). EP (10 mg ml-1) was incubated in these enzyme solutions at $25^{\circ} \mathrm{C}$ for $30 \mathrm{~min}$ and then equivalent concentrations of enzyme inhibitor were added: trypsin inhibitor was used for trypsin, chymotrypsin inhibitor for chymotrypsin, and $\alpha_{2}$-macroglobulin for papain and pronase. Bromelain (Boehringer) and $\alpha$-mannosidase (Sigma) (both $1 \mathrm{mg} \mathrm{ml}^{-1}$ ) in $0.04 \mathrm{M}$-sodium acetate buffer ( $\mathrm{pH} \mathrm{4.5)}$ were incubated with EP $\left(10 \mathrm{mg} \mathrm{ml}^{-1}\right.$ ) at $37^{\circ} \mathrm{C}$ for $60 \mathrm{~min}$. For treatment with endoglycosidase $\mathrm{H}$ (Miles), EP $\left(1 \mathrm{mg}\right.$ ) was incubated at $37^{\circ} \mathrm{C}$ for $2 \mathrm{~h}$ with $1 \mu \mathrm{g}$ enzyme at pH 5.6. Endoglycosidase-treated EP was applied to a small column of Con A-Sepharose. Unbound components were eluted from the column with PBS while bound material was eluted with $0.5 \mathrm{M}$-methyl $\alpha$-D-mannoside. Both fractions (bound and unbound) were dialysed against distilled water at $4{ }^{\circ} \mathrm{C}$, freeze-dried and redissolved in PBS (1 ml).

\section{RESULTS}

\section{Yield and chemical composition of EP}

EP was isolated by freeze-drying dialysed culture supernatants of $C$. albicans GDH 2346 . Growth for $5 \mathrm{~d}$ in 1 litre medium produced $8.23 \pm 0.62 \mathrm{~g}$ yeast (dry wt) (mean \pm SEM) and 1.82 $\pm 0.04 \mathrm{~g} \mathrm{EP}$ (dry wt). This represents an EP yield of $18 \%$, similar to that obtained previously by precipitation of culture supernatants with acetone (McCourtie \& Douglas, 1985). The chemical 


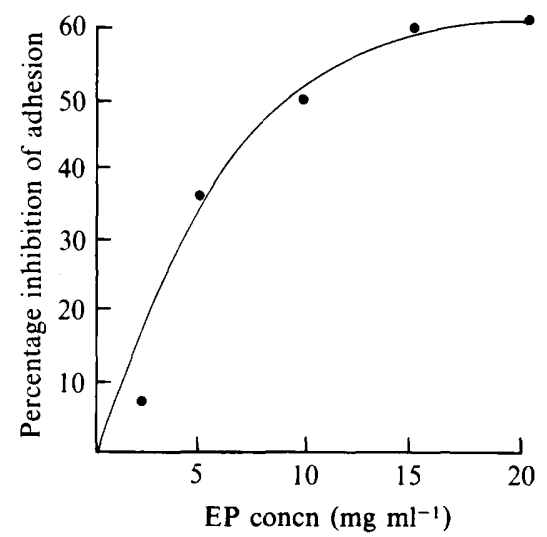

Fig. 1. Effect of crude EP on adhesion of $C$. albicans GDH 2346 to buccal epithelial cells. Buccal cells were pretreated with a solution of EP $\left(2-20 \mathrm{mg} \mathrm{ml}^{-1}\right.$ in PBS) at $37^{\circ} \mathrm{C}$ for $30 \mathrm{~min}$, and then used in adhesion assays with a yeast concentration of $5 \times 10^{7}$ organisms $\mathrm{ml}^{-1}$. Results shown represent mean values from assays done in triplicate.

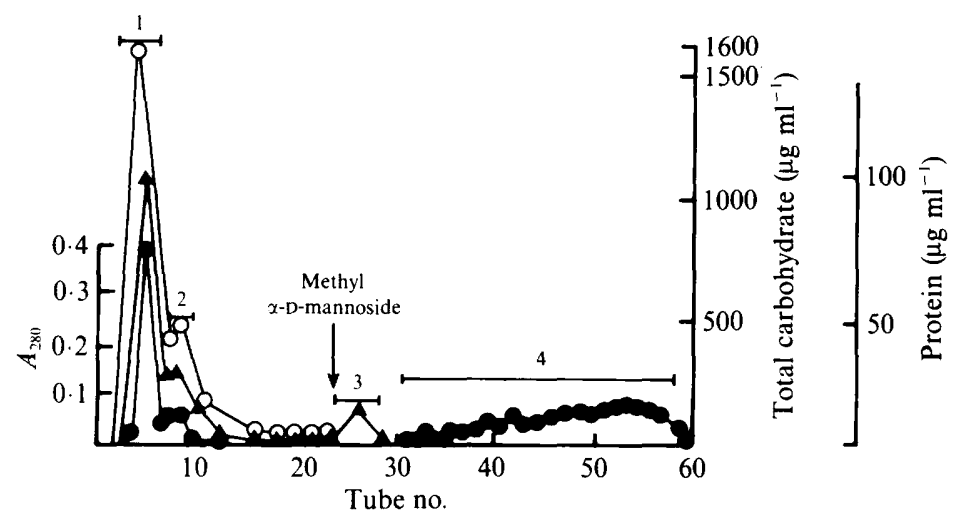

Fig. 2. Affinity chromatography of crude EP from C. albicans GDH 2346 on Con A-Sepharose. EP ( $30 \mathrm{mg}$ in PBS) was applied to the column and eluted with PBS until the absorbance at $280 \mathrm{~nm}$ of the eluate was negligible. Bound material was eluted with $0.5 \mathrm{M}$-methyl $\alpha$-D-mannoside as shown by the arrow. $\boldsymbol{A}_{280} ; O$, total carbohydrate; $\boldsymbol{\Delta}$, protein. Horizontal bars (numbered $1-4$ ) indicate fractions which were pooled after analysis.

composition was also similar to that of acetone-precipitable material, comprising $70 \cdot 0 \pm 2 \cdot 6 \%$ carbohydrate (mean $\pm \mathrm{SEM}$ ), $10.0 \pm 0.7 \%$ protein and $0.49 \pm 0.04 \%$ phosphorus.

\section{Effect of EP on yeast adhesion in vitro}

Preincubation of buccal epithelial cells with increasing concentrations (2-20 $\left.\mathrm{mg} \mathrm{ml}^{-1}\right)$ of EP inhibited yeast adhesion by up to $60 \%$ (Fig. 1). There was no further increase in inhibition at higher concentrations of EP. Adhesion to mouse vaginal epithelial cells in vitro was inhibited to a similar extent; pretreatment of these cells with EP $\left(10 \mathrm{mg} \mathrm{ml}^{-1}\right)$ at $37^{\circ} \mathrm{C}$ for 30 min resulted in a $51 \%$ decrease in adhesion.

\section{Fractionation of EP}

Affinity chromatography of EP on Con A-Sepharose (Fig. 2) resulted in elution of two components (fractions 1 and 2) before the addition of methyl $\alpha$-D-mannoside. Both components contained carbohydrate and protein. Material eluted after mannoside addition (fractions 3 and 4), and monitored by its absorbance at $280 \mathrm{~nm}$ or protein content, appeared to separate poorly. A more satisfactory separation was achieved by chromatography of this material on DEAEcellulose (Fig. 3) which produced two distinct components (fractions 5 and 6), each containing both carbohydrate and protein. 


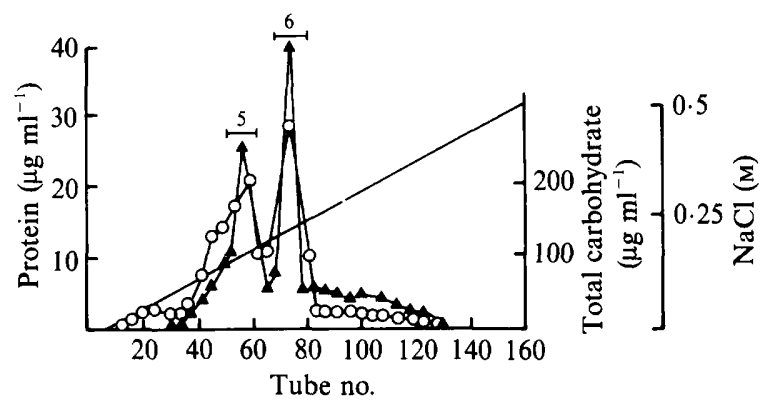

Fig. 3. DEAE-cellulose chromatography of Con A-bound EP. Material eluted from Con A-Sepharose with methyl $\alpha$-D-mannoside (Fig. 2) was dialysed, concentrated and applied to a column of DE 52 . This column was eluted with a linear gradient $(0-0.5 \mathrm{M})$ of $\mathrm{NaCl}$ in $0.15 \mathrm{M}$-potassium phosphate buffer (pH 7.2). $\Delta$, Protein; $O$, total carbohydrate. Horizontal bars (numbered 5 and 6 ) indicate fractions which were pooled after analysis.

Table 1. Effect of EP fractions isolated by chromatography on Con A-Sepharose and DEAEcellulose on adhesion of C. albicans GDH 2346 to buccal epithelial cells

Buccal epithelial cells were incubated at $37^{\circ} \mathrm{C}$ for $30 \mathrm{~min}$ either in PBS or in an EP fraction ( $1 \mathrm{ml}$ ) obtained by column chromatography. After this pretreatment, buccal cells were recovered by centrifugation, resuspended in PBS and used in adhesion assays. Assays were done three times in triplicate with a yeast concentration of $5 \times 10^{7}$ organisms $\mathrm{ml}^{-1}$.

\begin{tabular}{lcr}
\multicolumn{1}{c}{ EP fraction* } & $\begin{array}{c}\text { Mean no. }( \pm \text { SEM) of adherent } \\
\text { yeasts per } 100 \text { epithelial cells }\end{array}$ & $\begin{array}{r}\text { Percentage } \\
\text { of adh }\end{array}$ \\
1 & $1738 \pm 25$ \\
2 & $1572 \pm 72$ & 17 \\
3 & $1728 \pm 54$ \\
4 & $977 \pm 67$ \\
None (PBS control) & $1902 \pm 36$ \\
5 & $975 \pm 60$ \\
6 & $1658 \pm 65$ \\
None (PBS control) & $1739 \pm 45$
\end{tabular}

* Numbers refer to column fractions indicated by bars in Figs 2 and 3. Fractions 1-4 were isolated by chromatography of crude EP on Con A-Sepharose; fractions 5 and 6 were obtained by further separation of Con A-bound material on DEAE-cellulose.

$\dagger$ Inhibition obtained with EP-treated epithelial cells when compared with adhesion to PBS-treated epithelial cells.

The ability of each fraction to inhibit yeast adhesion in vitro was tested in standard adhesion assays. Preincubation of buccal cells with Con A-bound material (fraction 4) resulted in maximum inhibition; after further chromatography on DEAE-cellulose, inhibitory activity was localized in fraction 5 (Table 1). To determine the extent to which purification of yeast adhesin had been achieved, an adhesion inhibition index (AII) was calculated for each fraction (Table 2). AII is a measure of the relative efficiency with which each fraction inhibits adhesion as compared with crude, unfractionated EP. At a concentration of $10 \mathrm{mg} \mathrm{ml}^{-1}$, crude EP inhibits adhesion by $50 \%$ (Fig. 1). In calculating AII, the weights of protein and carbohydrate in each fraction required to inhibit adhesion by $50 \%$ were determined. The respective weights of protein and carbohydrate in $10 \mathrm{mg}$ crude EP (i.e. $1 \mathrm{mg}$ and $7 \mathrm{mg}$ ) were then divided by these values. The results (Table 2) indicate that this two-step separation protocol, involving chromatography on Con A-Sepharose and DEAE-cellulose, allows a 30-fold purification of yeast adhesin (fraction $5)$.

Treatment of EP with heat, chemicals and enzymes

Crude EP preparations were subjected to a variety of treatments with heat, chemicals and enzymes in an attempt to determine the minimum structure necessary for inhibition of yeast 
Table 2. Purification of yeast adhesin by chromatography on Con A-Sepharose and $D E A E$-cellulose: AII of EP fractions

\begin{tabular}{|c|c|c|c|c|c|}
\hline \multirow[b]{2}{*}{ EP fraction* } & \multicolumn{3}{|c|}{ Composition of EP fraction } & \multirow{2}{*}{$\begin{array}{c}\text { Based on } \\
\text { carbohydrate } \\
\text { content }\end{array}$} & \multirow[b]{2}{*}{$\begin{array}{c}\text { Based on } \\
\text { protein } \\
\text { content }\end{array}$} \\
\hline & $\begin{array}{c}\text { Carbohydrate } \\
\left(\mu \mathrm{g} \mathrm{ml}^{-1}\right)\end{array}$ & $\begin{array}{c}\text { Protein } \\
\left(\mu \mathrm{g} \mathrm{ml}^{-1}\right)\end{array}$ & $\begin{array}{c}\text { Carbohydrate: } \\
\text { protein ratio }\end{array}$ & & \\
\hline 1 & 728 & 70 & $10 \cdot 4$ & 2 & 3 \\
\hline 2 & 528 & 40 & $13 \cdot 2$ & 5 & 9 \\
\hline 3 & 0 & 10 & - & 0 & 18 \\
\hline 4 & 240 & 70 & $3 \cdot 4$ & 28 & 14 \\
\hline 5 & 190 & 28 & $6 \cdot 7$ & 32 & 31 \\
\hline 6 & 342 & 44 & $7 \cdot 7$ & 2 & 3 \\
\hline
\end{tabular}

* Numbers refer to column fractions indicated by bars in Figs 2 and 3. Fractions 1-4 were isolated by chromatography of crude EP on Con A-Sepharose; fractions 5 and 6 were obtained by further separation of Con A-bound material on DEAE-cellulose. All fractions were dialysed and concentrated before use in adhesion assays.

$\dagger$ AII is a measure of the relative efficiency with which each fraction inhibited adhesion as compared with crude $\mathrm{EP}$, and was calculated as described in the text.

Table 3. Effect of heat, chemical and enzyme treatments on the ability of crude EP to inhibit adhesion of C. albicans GDH 2346 to buccal epithelial cells

Buccal epithelial cells were incubated at $37^{\circ} \mathrm{C}$ for $30 \mathrm{~min}$ in a solution $\left(10 \mathrm{mg} \mathrm{ml}^{-1}\right)$ of EP pretreated as indicated. Control buccal cell preparations were incubated under the same conditions in PBS. Adhesion assays, with parallel controls, were done three times in triplicate, normally with a yeast cell concentration of $1 \times 10^{7}$ organisms $\mathrm{ml}^{-1}$.

Pretreatment of EP

\section{None}

$50^{\circ} \mathrm{C}, 15 \mathrm{~min}$

$80^{\circ} \mathrm{C}, 15 \mathrm{~min}$

$100^{\circ} \mathrm{C}, 15 \mathrm{~min}$

Periodate $(20 \mathrm{~mm})$

Periodate $(50 \mathrm{~mm})$

Dithiothreitol

Mild acid

Mild alkali

$\alpha$-Mannosidase

$$
\begin{gathered}
\text { Relative } \\
\text { adhesion }(\%) \dagger
\end{gathered}
$$

50
64
85
99
51
55
97
92
45
59

Pretreatment of EP

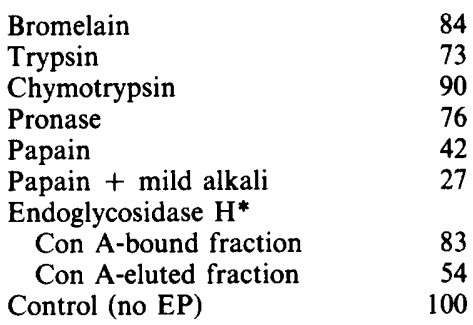

* Endoglycosidase H-treated EP was separated into 2 fractions on Con A-Sepharose as described in Methods.

$\dagger$ Adhesion is expressed as a percentage of that to control (PBS-treated) buccal cells for which, typically, a value of $897 \pm 38$ adherent yeasts per 100 epithelial cells (mean \pm SEM) was obtained.

adhesion in vitro. These studies indicated that the protein portion of the mannoprotein adhesin is more important than the carbohydrate moiety in mediating attachment to buccal epithelial cells. Pretreatment of EP with heat, dithiothreitol or $0.01 \mathrm{M}-\mathrm{HCl}$ destroyed its ability to inhibit adhesion (Table 3). Similarly, all of the proteolytic enzymes tested, except papain, significantly decreased $(P<0.001$, by Student's $t$-test) the inhibitory activity of EP. On the other hand, treatment with periodate or $\alpha$-mannosidase had no significant effect. Preincubation of EP with papain or dilute alkali appeared to enhance its ability to inhibit adhesion, while a combined treatment of papain followed by alkali produced substantially greater inhibition $(P<0.001$; Table 3). In all of these experiments, control assays were included which demonstrated that none of the pretreatments per se (i.e. in the absence of EP) significantly affected yeast adhesion. Additional experiments also indicated that periodate and $\alpha$-mannosidase treatments effectively degraded the carbohydrate component of EP.

Further evidence for the importance of the protein portion of EP in mediating adhesion came from experiments with endoglycosidase $\mathrm{H}$, an endo- $\beta$ - $N$-acetylglucosaminidase capable of 
hydrolysing the di- $\mathrm{N}$-acetylchitobiose units which link polymannose chains to asparagine residues in yeast mannoproteins (Tarentino et al., 1974). Endoglycosidase $\mathrm{H}$-treated EP was chromatographed on Con A-Sepharose and both Con A-bound and Con A-eluted fractions were tested for their ability to inhibit yeast adhesion. The eluted, protein-rich fraction inhibited adhesion more effectively $(P<0.001)$ than the Con A-bound, carbohydrate-rich material (Table 3).

\section{DISCUSSION}

Adhesion of micro-organisms to mucosal surfaces is thought to involve specific, lectin-like interactions between microbial adhesins and complementary host-cell receptors. Attempts to characterize these adhesive surface structures often entail adding putative adhesin or receptor (or their analogues) to in vitro adhesion assays; either component will block adhesion by acting as a competitive inhibitor (Ofek \& Beachey, 1980). This approach was used in a previous study of $C$. albicans adhesion (McCourtie \& Douglas, 1985), where pretreatment of buccal epithelial cells with EP from galactose-grown yeasts was shown to inhibit subsequent yeast adhesion. The specificity of the interaction was demonstrated by the finding that EP from one $C$. albicans strain (GDH 2023) did not inhibit adhesion of a second strain (GDH 2346). In that earlier study, EP was isolated from culture supernatants by precipitation with acetone. In the present investigation, however, EP was obtained by freeze-drying to minimize the possibility of denaturation or aggregation of individual components. The two methods produced EP in similar yields and with a similar overall chemical composition.

Adhesion inhibition tests were used to monitor purification of an EP component which could block yeast adhesion to buccal epithelial cells. Unfractionated EP inhibited adhesion by up to $60 \%$. During affinity chromatography on Con A-Sepharose, most of the inhibitory activity was localized in material that bound to the lectin. This finding is consistent with earlier analyses (McCourtie \& Douglas, 1985), and with experiments involving the antibiotic tunicamycin (Douglas \& McCourtie, 1983), which suggested that the yeast adhesin is mannoprotein in nature. Further chromatography of Con A-bound material on DEAE-cellulose produced two fractions, only one of which contained substantial inhibitory activity. On a weight basis (protein or carbohydrate content), this purified material inhibited yeast adhesion to buccal cells 30 times more efficiently than crude EP. It is not yet clear whether more than one type of adhesin is present in this fraction. Preliminary attempts at further separation by gel electrophoresis were unsuccessful. However, experiments described in the accompanying paper (Critchley \& Douglas, 1987) indicate that $C$. albicans GDH 2346 does possess more than one adhesin for buccal cells.

C. albicans can adhere to a variety of epithelial cell types in addition to buccal cells. These include vaginal (King et al., 1980; Sobel et al., 1981) and uro-epithelial cells (Botta, 1981; Centeno et al., 1983), as well as epidermal corneocytes (Botta, 1981; Ray et al., 1984; CollinsLech et al., 1984). Crude EP inhibited adhesion to mouse vaginal cells and the extent of inhibition observed was similar to that obtained with buccal cells. This indicates that EP contains an adhesin for vaginal cells, although whether this yeast surface component is identical with the adhesin(s) responsible for attachment to buccal cells remains to be determined.

There is now considerable evidence that $C$. albicans adhesins for both buccal and vaginal epithelial cells are mannoprotein in nature (Sandin et al., 1982; Douglas \& McCourtie, 1983; Lee \& King, 1983a, b; McCourtie \& Douglas, 1985), but it is not yet certain whether the carbohydrate or protein portion of the mannoprotein molecule is more important in the adhesion process. Bacterial adhesion to animal cells can be mediated by carbohydrate-lectin interactions (Ofek \& Perry, 1985) in three ways: (i) a bacterial surface protein (lectin) binds to glycosides on the animal cell membrane; (ii) extracellular lectin forms bridges between carbohydrates on the surface of both bacterial and animal cells; and (iii) lectin, present as an integral component of the animal cell membrane, binds to carbohydrate on the bacterial surface. With $C$. albicans, mannoprotein adhesins could permit all three types of interaction. In the present study, we tried to define more precisely the interaction with buccal cells by 'dissecting' crude EP preparations chemically or enzymically, and then determining the effect of these 
treatments on the ability of EP to inhibit yeast adhesion in vitro. The advantages of this indirect approach as compared with direct chemical or enzymic treatment of yeast cells are that the effect is a specific one, limited to EP, and that yeast viability is not affected. Pretreatment of EP with heat, dithiothreitol or proteolytic enzymes (except papain) either partially or completely destroyed its ability to inhibit adhesion, whereas pretreatment with sodium periodate or $\alpha$ mannosidase had little or no effect. Moreover, the protein-rich fraction obtained by incubating EP with endoglycosidase $\mathrm{H}$ inhibited adhesion to a greater extent than did the carbohydraterich fraction. These results seem to indicate that the predominant interaction between yeasts and buccal cells is one involving the protein portion of the mannoprotein adhesin. Such a mechanism would be analogous to that found in many Gram-negative bacteria where adhesion to mucosal surfaces is mediated by proteinaceous, carbohydrate-binding adhesins (Jones \& Isaacson, 1983).

Adhesion of $C$. albicans to vaginal cells can be severely inhibited by subjecting the yeasts to direct treatment with a variety of different proteolytic enzymes (Sobel et al., 1981; Lee \& King, $1983 a$ ) or reducing agents such as 2-mercaptoethanol and dithiothreitol. By contrast, glycosidases have little effect (Lee \& King, 1983a). Papain treatment of $C$. albicans has been reported to release a small mannoprotein which inhibits yeast adhesion to vaginal cells (Lee \& King, 1983b). Incubation of EP with papain enhanced its ability to inhibit adhesion to buccal cells, while a combination of papain treatment followed by dilute alkali resulted in notably increased inhibition. Exposure to dilute alkali causes $\beta$-elimination of manno-oligosaccharides attached to serine and threonine residues in yeast mannoproteins (Sentandreu \& Northcote, 1968). Presumably, digestion of EP with both papain and alkali produces peptide fragments which can more easily bind to epithelial cell receptors.

I.A.C. was the recipient of an SERC-CASE studentship awarded in collaboration with ICI Pharmaceuticals Division. We are grateful to ICI for additional financial support.

\section{REFERENCES}

Barnes, J. L., Osgood, R. W., Lee, J. C., King, R. D. \& STEIN, J. H. (1983). Host-parasite interactions in the pathogenesis of experimental renal candidiasis. Laboratory Investigation 49, 460-467.

BotTA, G. A. (1981). Possible role of hormones in the observed changes in adhesion of several microorganisms to epithelial cells from different body sites. FEMS Microbiology Letters 11, 69-72.

Centeno, A., Davis, C. P., Cohen, M. S. \& Warren, M. M. (1983). Modulation of Candida albicans attachment to human epithelial cells by bacteria and carbohydrates. Infection and Immunity 39, 13541360.

Chen, P. S., Toribara, T. Y. \& Warner, H. (1956). Microdetermination of phosphorus. Analytical Chemistry 28, 1756-1758.

Collins-Lech, C., Kalbfleisch, J. H., Franson, T. R. \& SoHNLE, P. G. (1984). Inhibition by sugars of Candida albicans adherence to human buccal mucosal cells and corneocytes in vitro. Infection and Immunity 46, 831-834.

Critchley, I. A. \& Douglas, L. J. (1987). Role of glycosides as epithelial cell receptors for Candida albicans. Journal of General Microbiology 133, 637643.

Douglas, L. J. (1985). Adhesion of pathogenic Candida species to host surfaces. Microbiological Sciences 2, 243-247.

Douglas, L. J. (1987). Adhesion to surfaces. In The Yeasts, 2nd edn, vol. 2, pp. 239-280. Edited by A. H. Rose \& J. S. Harrison. London: Academic Press.
Douglas, L. J. \& McCourtie, J. (1983). Effect of tunicamycin treatment on the adherence of Candida albicans to human buccal epithelial cells. FEMS Microbiology Letters 16, 199-202.

Douglas, L. J., Houston, J. G. \& McCourtie, J. (1981). Adherence of Candida albicans to human buccal epithelial cells after growth on different carbon sources. FEMS Microbiology Letters 12, 241243.

Dubois, M., Gilles, K. A., Hamilton, J. K., Rebers, P. A. \& SMITH, F. (1956). Colorimetric method for determination of sugars and related substances. Analytical Chemistry 28, 350-356.

Jones, G. W. \& IsAaCson, R. E. (1983). Proteinaceous bacterial adhesins and their receptors. CRC Critical Reviews in Microbiology 10, 229-260.

King, R. D., LEE, J. C. \& MorRIS, A. L. (1980). Adherence of Candida albicans and other Candida species to mucosal epithelial cells. Infection and Immunity 27, 667-674.

LEE, J. C. \& KING, R. D. (1983a). Characterization of Candida albicans adherence to human vaginal epithelial cells in vitro. Infection and Immunity 41, 10241030.

LeE, J. C. \& KING, R. D. (1983b). Adherence mechanisms of Candida albicans. In Microbiology1983, pp. 269-272. Edited by D. Schlessinger. Washington, DC: American Society for Microbiology.

Marrie, T. J. \& Costerton, J. W. (1981). The ultrastructure of Candida albicans infections. Canadian 
Journal of Microbiology 27, 1156-1164.

McCourtie, J. \& Douglas, L. J. (1981). Relationship between cell surface composition of Candida albicans and adherence to acrylic after growth on different carbon sources. Infection and Immunity 32, 12341241 .

McCourtie, J. \& Douglas, L. J. (1984). Relationship between cell surface composition, adherence and virulence of Candida albicans. Infection and Immunity 45, 6-12.

McCourtie, J. \& Douglas, L. J. (1985). Extracellular polymer of Candida albicans: isolation, analysis and role in adhesion. Journal of General Microbiology 131, 495-503.

OFEK, I. \& BEACHEY, E. H. (1980). General concepts and principles of bacterial adherence in animals and man. In Bacterial Adherence, Receptors and Recognition, series B, vol. 6, pp. 1-29. Edited by E. H. Beachey. London: Chapman \& Hall.

OfEK, I. \& PERRY, A. (1985). Molecular basis of bacterial adherence to tissues. In Molecular Basis of Oral Microbial Adhesion, pp. 7-13. Edited by S. E. Mergenhagen \& B. Rosan. Washington, DC: American Society for Microbiology.
Ray, T. L., Digre, K. B. \& Payne, C. D. (1984). Adherence of Candida species to human epidermal corneocytes and buccal mucosal cells: correlation with cutaneous pathogenicity. Journal of Investigative Dermatology 83, 37-41.

Sandin, R. L., Rogers, A. L., Patterson, R. J. \& BENEKE, E. S. (1982). Evidence for mannosemediated adherence of Candida albicans to human buccal cells in vitro. Infection and Immunity 35, 79-85.

Sentandreu, R. \& Northcote, D. H. (1968). The structure of a glycopeptide isolated from the yeast cell wall. Biochemical Journal 109, 419-432.

Sobel, J. D., Myers, P. G., Kaye, D. \& Levison, M. E. (1981). Adherence of Candida albicans to human vaginal and buccal epithelial cells. Journal of Infectious Diseases 143, 76-82.

Tarentino, A. L., Plummer, T. H., JR \& Maley, F. (1974). The release of intact oligosaccharides from specific glycoproteins by endo- $\beta-N$-acetylglucosaminidase H. Journal of Biological Chemistry 249, 818824. 